\author{
WIESŁAWA GIERAŃCZYK, ARKADIUSZ STAŃCZYK \\ UMK, Toruń
}

\title{
Korporacje międzynarodowe w przestrzeni globalnej
}

Na wstępie warto zastanowić się, czym jest globalizacja w aspekcie przedsiębiorstwa? Najogólniej można powiedzieć, że globalizacja firm oznacza zaawansowane umiędzynarodowienie ich działalności, które polega na funkcjonalnej integracji rozproszonych po świecie jednostek organizacyjnych. Założenie to najpełniej realizowane jest przez największe przedsiębiorstwa, które sukcesywnie i konsekwentnie rozszerzają zasięg swego działania m.in. poprzez łączenie się przedsiębiorstw w coraz większe organizmy gospodarcze, które dysponując coraz większą siłą mogą dyktować warunki innym uczestnikom rynku. Integracja ekonomiczna przedsiębiorstw może mieć różny przebieg, skalę i zasięg. $\mathrm{O}$ integracji poziomej mówi się, gdy w skład organizacji integracyjnej wchodzą przedsiębiorstwa wytwarzające takie same lub podobne produkty, natomiast o pionowej, gdy łączą się przedsiębiorstwa różnych gałęzi i branż, uczestniczące w kolejnych fazach procesu produkcji dobra finalnego. Kiedy między przedsiębiorstwami zachodzą relacje pionowe i poziome tworzą się konglomeraty. Przedsiębiorstwa powiększają swój potencjał m.in. poprzez podejmowanie wspólnych inwestycji, dobrowolne łączenie się, fuzje i przejęcia lub też wchłanianie mniejszych. Największe przedsiębiorstwa, zwane korporacjami, w celu osiągnięcia dominującej pozycji na rynku światowym coraz intensywniej dążą do pozyskiwania wpływów poza granicami własnego kraju. Przyjmuje się, że firmy, których aktywa zlokalizowane są

w co najmniej dwóch krajach to przedsiębiorstwa (korporacje) międzynarodowe. Najbardziej rozpowszechnionym sposobem rozwoju korporacji międzynarodowych jest tworzenie oddziałów za granicą poprzez lokalizację nowej fabryki w danym kraju lub poprzez wykupienie przedsiębiorstwa (posiadanie pakietu pozwalającego na kontrolę przedsiębiorstwem) już istniejącego na rynku lokalnym. Korporacje kontrolujące rynek w wielu krajach uważane są za istotne, jeśli nie najważniejsze elementy budujące światowy system transferu środków kapitałowych, obejmujących bezpośrednie inwestycje zagraniczne (BIZ). Wyraźna ekspansja korporacji międzynarodowych jest jednym z najważniejszych przejawów globalizacji.

Identyfikując przedsiębiorstwa o zasięgu międzynarodowym zauważa się, że w literaturze oraz obiegu gospodarczym występuje kilka określeń dla tego typu przedsiębiorstw (korporacji), m.in.:
- wielonarodowe,
- międzynarodowe,
- transnarodowe, 
- ponadnarodowe,

- multinarodowe,

- globalne.

Niejednokrotnie określenia te używane są zamiennie lub jako pojęcia bliskoznaczne. Tymczasem analiza struktur organizacyjnych korporacji międzynarodowych ${ }^{*}$ pozwala zauważyć, że poszczególne terminy w dużej mierze odzwierciedlają poziom umiędzynarodowienia danej korporacji, mierzony np. odsetkiem sprzedaży na eksport, udziałem zatrudnionych

w filiach zagranicznych, wartością majątku za granica, udziałem produkcji zagranicznej w całkowitej produkcji czy zyskiem powstałym z operacji zagranicznych. Przedstawione kryteria pozwalają wydzielić następujące typy korporacji o zasięgu globalnym (tab. 1):

Tabela 1. Korporacje według poziomu umiędzynarodowienia

\begin{tabular}{|c|c|c|c|c|c|}
\hline $\begin{array}{c}\text { Typ } \\
\text { korporacji }\end{array}$ & $\begin{array}{c}\text { Udział } \\
\text { eksportu } \\
\text { w całkowitej } \\
\text { sprzedaży }\end{array}$ & $\begin{array}{c}\text { Udział } \\
\text { produkcji } \\
\text { zagranicznej } \\
\text { w całkowitej } \\
\text { produkcji } \\
\end{array}$ & $\begin{array}{l}\text { Udział majątku } \\
\text { za granicą }\end{array}$ & $\begin{array}{c}\text { Zysk } \\
\text { powstały } \\
\text { z operacji } \\
\text { zagranicznych }\end{array}$ & $\begin{array}{c}\text { Formy } \\
\text { działalności }\end{array}$ \\
\hline $\begin{array}{l}\text { między- } \\
\text { narodowa }\end{array}$ & $\begin{array}{l}\text { wyraźnie } \\
\text { widoczny, } \\
\text { przeważa } \\
\text { jednak sprzedaż } \\
\text { krajowa }\end{array}$ & $\begin{array}{l}\text { znaczący, } \\
\text { ale niższy } \\
\text { od udziału } \\
\text { eksportu }\end{array}$ & niewielki & $\begin{array}{l}\text { podobny } \\
\text { do udziału } \\
\text { eksportu }\end{array}$ & $\begin{array}{l}\text { posiadanie oddziałów } \\
\text { zagranicznych, które } \\
\text { funkcjonują na zasa- } \\
\text { dzie zintegrowanych } \\
\text { działań ekonomicz- } \\
\text { nych }\end{array}$ \\
\hline $\begin{array}{l}\text { wielona- } \\
\text { rodowa }\end{array}$ & $\begin{array}{l}\text { osiaga lub } \\
\text { nieco przekracza } \\
50 \%\end{array}$ & $\begin{array}{l}\text { zbliżony } \\
\text { do udziału } \\
\text { eksportu }\end{array}$ & $\begin{array}{l}\text { wyższy niż wy- } \\
\text { żej, ale nadal } \\
\text { niższy niż udział } \\
\text { eksportu }\end{array}$ & $\begin{array}{l}\text { równy } \\
\text { lub wyższy } \\
\text { niż udział } \\
\text { eksportu } \\
\text { w sprzedaży }\end{array}$ & $\begin{array}{l}\text { liczne jednostki za- } \\
\text { graniczne podległe } \\
\text { powstającym subcen- } \\
\text { trom zarządzającym, } \\
\text { przy tych korporacjach } \\
\text { powstają ośrodki } \\
\text { rozwojowe, laborato- } \\
\text { ria badawcze, uprzy- } \\
\text { wilejowana polityka } \\
\text { kadrowa, przejmowa- } \\
\text { nie wzorców kraju } \\
\text { macierzystego }\end{array}$ \\
\hline $\begin{array}{l}\text { transna- } \\
\text { rodowa }\end{array}$ & $\begin{array}{l}\text { przewyższa } \\
\text { sprzedaż } \\
\text { krajową }\end{array}$ & $\begin{array}{l}\text { przewyższa } \\
\text { krajową }\end{array}$ & $\begin{array}{l}\text { równy lub } \\
\text { wyższy niż } \\
\text { krajowego }\end{array}$ & $\begin{array}{l}\text { wyższy } \\
\text { od udziału } \\
\text { eksportu }\end{array}$ & $\begin{array}{l}\text { przezwyciężanie na- } \\
\text { rodowych ograniczeń, } \\
\text { nie ma już preferowa- } \\
\text { nia kultury, polityki } \\
\text { czy gospodarki jed- } \\
\text { nego kraju, kadra } \\
\text { zarządzająca pochodzi } \\
\text { z różnych krajów czę- } \\
\text { sto wg ścisłych norm } \\
\text { narodowościowych }\end{array}$ \\
\hline ponadna- & wyraźnie & udział wyraź- & wyraźnie wyż- & wyższy & dominująca pozycja \\
\hline
\end{tabular}

* W niniejszym opracowaniu przyjmuje się, że korporacje międzynarodowe to przedsiębiorstwa prowadzące działalność gospodarczą na terenie co najmniej dwóch krajów. 


\begin{tabular}{|l|l|l|l|l|l|}
\hline $\begin{array}{l}\text { rodowa } \\
\text { globalna) }\end{array}$ & dominuje & $\begin{array}{l}\text { nie przewyż- } \\
\text { sza sprzedaż } \\
\text { krajową }\end{array}$ & $\begin{array}{l}\text { szy od krajowe- } \\
\text { go, silnie roz- } \\
\text { proszony w } \\
\text { różnych krajach }\end{array}$ & $\begin{array}{l}\text { od udziału } \\
\text { eksportu }\end{array}$ & $\begin{array}{l}\text { na rynku danego } \\
\text { produktu w skali } \\
\text { światowej }\end{array}$ \\
\hline
\end{tabular}

Źródło: Czupiał 1997, s. 58

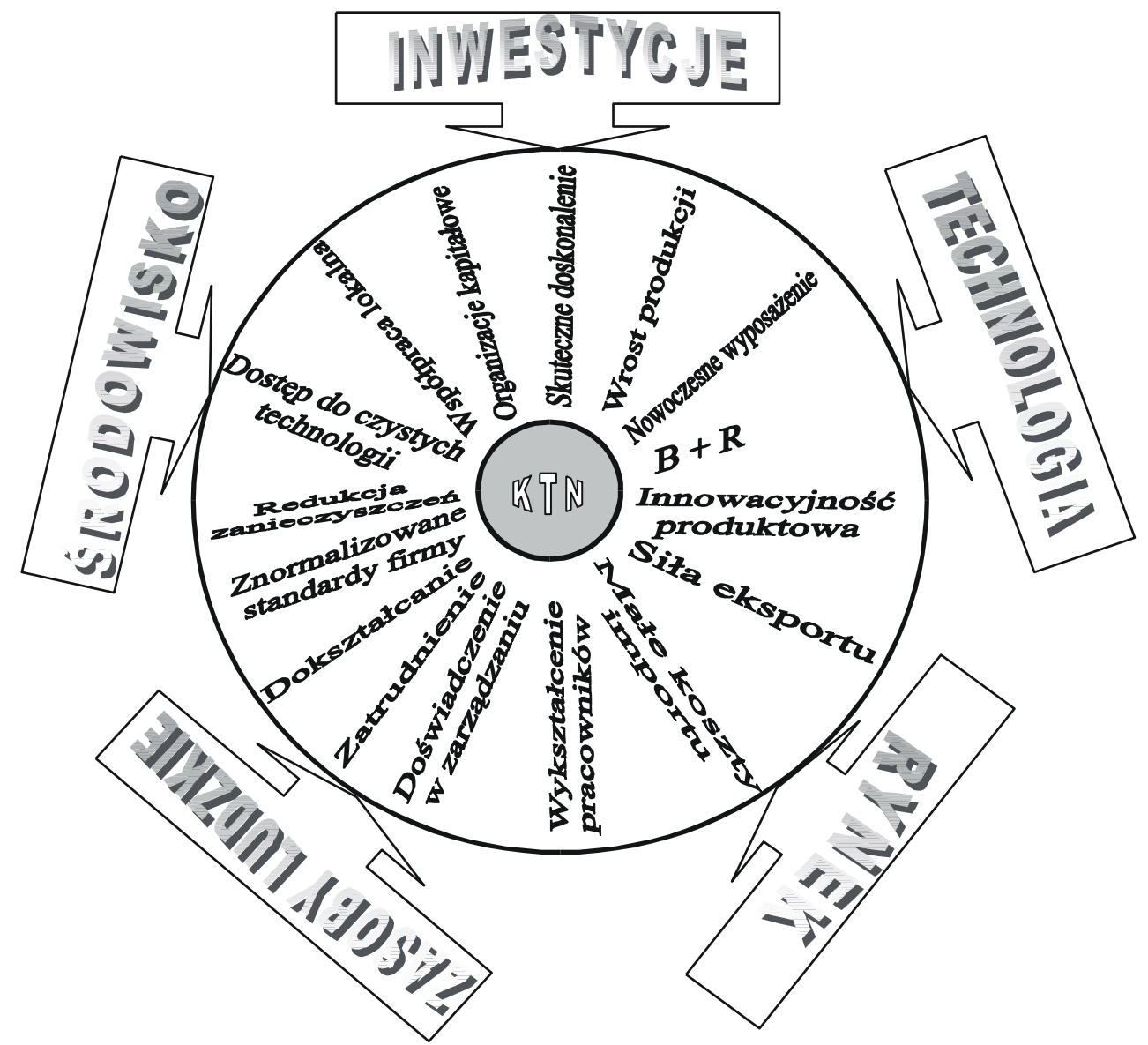

Ryc. 1. Czynniki wpływające na rozwój korporacji międzynarodowych (KTN)

Przyczyną powstawania i rozwoju korporacji międzynarodowych jest przede wszystkim poszukiwanie zasobów tanich i dobrych czynników produkcji, nowych, chłonnych rynków zbytu oraz możliwości uzyskania za granicą wyższej stopy zysku od zaangażowanego kapitału. Tworzenie zagranicznych filii daje możliwość ominięcia istniejących barier utrudniających eksport. Ważnym motywem jest nasilająca się konkurencja zarówno na rynkach lokalnych, jak i na rynku globalnym.

Korporacje międzynarodowe kierują swoją ekspansję głównie do krajów wysoko rozwiniętych, co jest spowodowane bardzo dużą chłonnością ich rynków wewnętrznych, jak również względami technologicznymi oraz stabilnością polityczną i społeczną w tych krajach. Głównym motywem inwestowania w krajach rozwijających się i słabo rozwiniętych jest dążenie do rozszerzenia rynków zbytu i obniżania kosztów wytwarzania poprzez lo- 
kowanie pracochłonnych procesów wytwórczych w tych krajach (niskie koszty pracy). Nie mniej ważne dla inwestorów są liczne ulgi inwestycyjne oferowane w krajach cierpiących na głód kapitału czy łagodniejsze normy ochrony środowiska. Powstawanie filii firm międzynarodowych w krajach słabiej rozwiniętych jest zwykle dla tych krajów korzystne, gdyż napływ kapitału zagranicznego pozwala na transfer technologii oraz systemów organizacji i zarządzania, wzrost produkcji, szczególnie wyrobów nowoczesnych o wysokiej jakości, rozbudowę i unowocześnienie infrastruktury, ożywienie działalności gospodarczej, rozwój rynku pracy, podnoszenie kwalifikacji i dyscypliny zatrudnionych, aktywizację lokalnego biznesu, wzmożenie konkurencji, rozbudowę kontaktów zagranicznych lokalnych przedsiębiorstw, rozwój systemu informacji gospodarczej, ochronę środowiska naturalnego, wzrost eksportu. Firmy krajowe, aby sprostać rosnącej konkurencji ze strony koncernów międzynarodowych, powielają ich działania, co prowadzi do tzw. efektu naśladownictwa. Czynniki wpływające na rozwój przedsiębiorstw międzynarodowych przedstawiono na rycinie 1.

Powstawanie przedsiębiorstw międzynarodowych ma długą historię i jest związane z ekspansją kolonialną Anglii i Niderlandów począwszy od wieku XVII. Takie firmy jak Kompania Wschodnioindyjska zaszczepiły nowe formy działalności gospodarczej na Dalekim Wschodzie, w Afryce czy w Ameryce. Korporacje międzynarodowe, znane obecnie, zaczęły powstawać w XIX wieku. Pożywką ich rozwoju był proces industrializacji połączony z rozwojem technologii produkcyjnych, akumulacją kapitału, kooperacji i transportu. Przez cały wiek XIX i początek XX korporacje międzynarodowe ograniczały swoja działalność w zasadzie do pozyskiwania surowców, przeróbki ropy naftowej i produkcji żywności. Blisko 60\% tych korporacji inwestowało w Ameryce Łacińskiej, Azji, Afryce i na Bliskim Wschodzie. Liczne fuzje i przejęcia $\mathrm{z}$ tego okresu w sektorze petrochemicznym i spożywczym przyczyniły się do powstania korporacji międzynarodowych, które przetrwały do naszych czasów. W Stanach Zjednoczonych gigant spożywczy United Fruit Company kontroluje $90 \%$ importu bananów już od 1899 roku. Do wybuchu I wojny światowej Royal Dutch/Shell uczestniczył w wydobyciu 20\% rosyjskiej ropy naftowej. O ile po I wojnie światowej impet firm europejskich do łączenia nieco osłabł, to w USA proces ten nabrał tempa. W tym czasie również w Japonii zaobserwowano początki tworzenia się wielkich przedsiębiorstw, m.in. Mitsui i Mitsubishi. Te gigantyczne korporacje współdziałały z państwem japońskim i utrzymywały oligopolistyczną kontrolę nad przemysłem, finansami

i handlem Japonii.

Wyraźna recesja w rozwoju korporacji międzynarodowych miała miejsce w latach 30 . XX w., co wynikało m.in. z szerzącego się niepokoju politycznego, związanego z faszyzmem i nazizmem oraz wybuchem II wojny światowej. Po II wojnie światowej przez blisko dwie dekady niepodzielnie na rynku światowym dominowały korporacje amerykańskie, podczas gdy koncerny europejskie i japońskie odbudowywały swoją pozycję na rynkach lokalnych. Sytuacja uległa zmianie w latach sześćdziesiątych, kiedy to rozpoczęła się ich ekspansja na dostępny wówczas rynek światowy (3. fala fuzji i przejęć). Sprzyjała temu integracja państw w ramach ugrupowań gospodarczych, takich jak EWWiS, EWG czy

Euroatom. Dążność do koncentracji kapitału w rękach najsilniejszych dała początek współczesnym międzynarodowym organizacjom konglomeratowym, szczególnie w takich dziedzinach działalności gospodarczej, jak transport, łączność czy elektronika.

$\mathrm{Na}$ początku lat 70 . funkcjonowało ok. 7 tys. korporacji międzynarodowych. W kolejnych dekadach zjawiska lokowania inwestycji za granicą przybierały na sile. Spowodo- 
wane to było całym zespołem czynników mikro- i makroekonomicznych. Niewątpliwie podejmowaniu ryzyka inwestycyjnego poza granicami sprzyjała generalnie dobra koniunktura gospodarcza, jak też postępująca globalizacja biznesu, która prowadziła do zwiększania korzyści skali i tworzenia przedsiębiorstw o zasięgu światowym. W owym czasie wzrosła też dostępność do rynków amerykańskich. Osłabienie dolara w drugiej połowie lat 80 . spowodowało, że przedsiębiorstwa amerykańskie stały się relatywnie tańsze i łatwiejsze do przejęcia przez inwestorów zagranicznych. O ile w latach 50, 60. i 70. ekspansja międzynarodowa obejmowała wielkie korporacje, o tyle w latach 80 . dołączyły do nich liczne małe i średnie przedsiębiorstwa. Na tę kategorię firm przypadało ponad 20\% wszystkich inwestycji bezpośrednich.

Znaczące nasilenie działań integracyjnych miało miejsce w latach dziewięćdziesiątych. Podczas gdy w 1990 r. funkcjonowało ok. 24 tys. przedsiębiorstw międzynarodowych z ponad 150 tys. filii zagranicznych, to u progu XXI wieku UNCTAD donosił o istnieniu ponad 63 tys. korporacji międzynarodowych posiadających ponad 820 tys. filii zagranicznych. Zatem w ciągu 30 ostatnich lat liczba korporacji międzynarodowych wzrosła 9-krotnie, a filii 25-krotnie. Można więc stwierdzić, że przedsiębiorstwa nadal kontynuują ekspansję terytorialną, obejmując swym zasięgiem coraz to nowe rejony świata. Sprzyja temu zacieranie się granic narodowych, których obsługa wymaga zwielokrotnionej skali działania i odpowiednio dużych zasobów, jak też zastosowanie Internetu i nowych mediów telekomunikacyjnych, dzięki którym odległość geograficzna traci na znaczeniu. Na skutek intensywnego procesu rozwoju korporacji międzynarodowych wzrasta ich udział zarówno w zasobach kapitałowych, jak i ludzkich światowej gospodarki. O ile w 1990 roku na jedną "firmę matkę" przypadało 6,25 filii, to w 1999 roku blisko 13 filii.

Świadczy to o silnej ekspansywności korporacji międzynarodowych w ostatnim dziesięcioleciu. Należy przy tym zauważyć, iż o ile firmy macierzyste koncentrują się w krajach członkowskich Unii Europejskiej (52,5\%), w USA $(5,3 \%)$, w Japonii $(6,8 \%)$, w Szwajcarii (7,1\%), w Korei Pd. (11,8\%), w Chinach (bez Hongkongu) (0,6\%) (ryc. 2), to

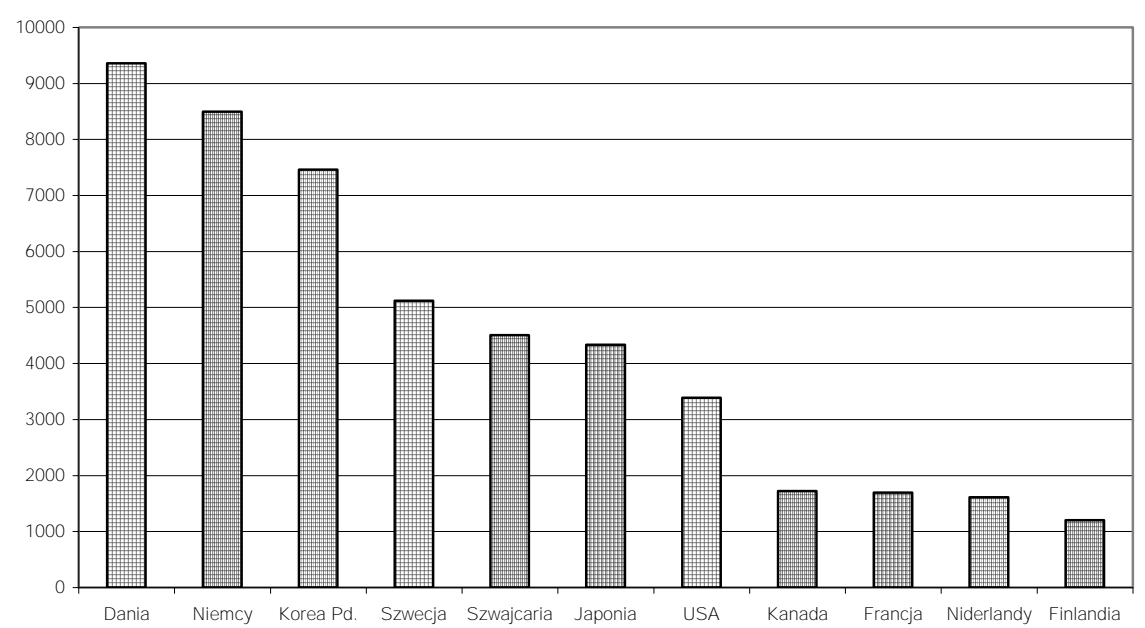

ponad połowa filii skupia się w Azji (55,5\%), przy czym na Chiny przypada ponad 44\% filii (ryc. 3). Drugim pod względem liczby filii obszarem jest Europa Środkowa i Wschodnia, na którą przypada 28,8\% firm. Europa Środkowa i Wschodnia, jak do tej pory, jedynie 


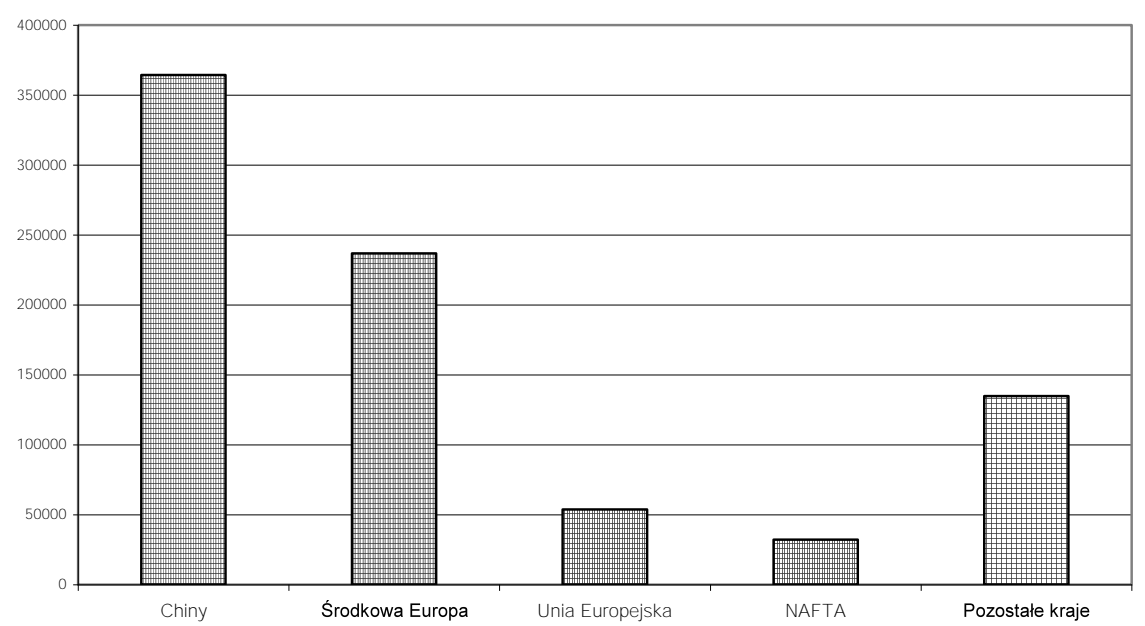

przyciaga inwestycje, a niewiele inwestuje za granica, gdyż na ten obszar przypada niespełna 1,2\% "firm matek". Natomiast na obszarze Unii Europejskiej skupionych jest 7,6\% ogółu filii,

w USA $2,3 \%$, a w Japonii jedynie $0,4 \%$. Strukture geograficzną rozmieszczenia filii przedstawiono na ryc. 4.

Ryc. 2. Geograficzne rozmieszczenie "firm matek" w wybranych krajach świata w 1999 roku

Źródło: World Investment Report, 2001, s. 239-242

$R y c$. 3. Filie międzynarodowych korporacji w wybranych regionach świata w 1999 roku

Źródło: World Investment Report, 2001, s. 239-242

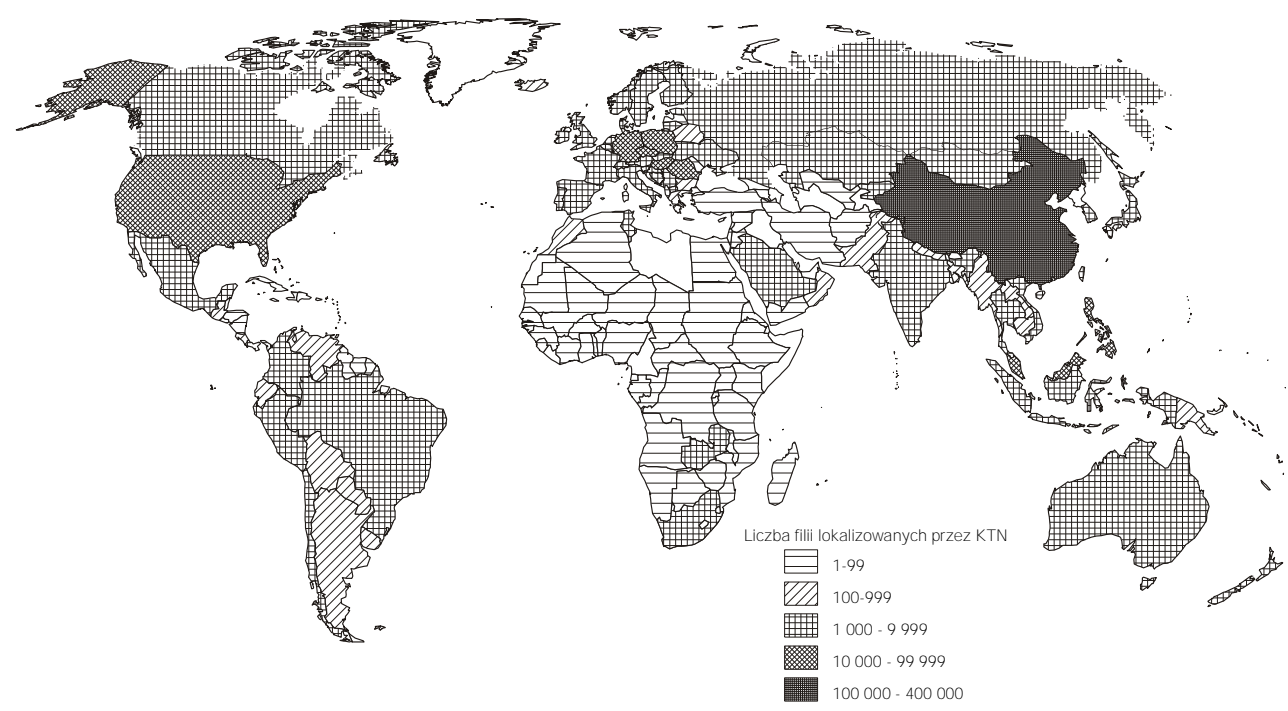

Ryc. 4. Geograficzne rozmieszczenie filii zagranicznych KTN w 1999 r.

Źródło: World Investment Report, 2001 
Wraz ze wzrostem liczby korporacji międzynarodowych oraz ich filii wzrastała liczba pracujących w tych firmach. W latach 80 . liczba pracujących w filiach wzrosła z 17,5 mln w 1982 roku do $23,7 \mathrm{mln}$ w 1990 roku. W ciagu następnego dziesięciolecia liczba ta prawie się podwoiła, gdyż w 2000 roku filie dawały miejsca pracy dla 45,6 mln osób w 174 krajach na świecie.

Dynamiczny pod każdym względem rozwój korporacji globalnych wskazuje, iż tworzenie coraz większej liczby filii korporacji międzynarodowych jest preferowaną metodą rozwoju międzynarodowego. $Z$ badań wynika bowiem, iż przepływy w przedsiębiorstwach międzynarodowych przewyższają eksport.

Dynamikę eksportu oraz BIZ w latach 1975-1989 ilustruje ryc. 5. Wyraźny wzrost inwestycji bezpośrednich rozpoczął się pod koniec lat 80 . i związany był $\mathrm{z}$ wejściem na ścieżkę wzrostu gospodarki amerykańskiej i japońskiej. Tendencje te kontynuowane były w latach 90. O ile w 1990 roku inwestycje zagraniczne korporacji macierzystych wynosiły 209 mld USD, to w 1999 roku 865 mld USD, a zatem nastapił wzrost o 313,9\%. W tym samym okresie wartość eksportu wzrosła o 64,7\% - z 3,4 bln USD w 1990 roku do 5,6 bln USD w 1999 roku. Jednocześnie eksport z filii koncernów międzynarodowych wzrósł w tym samym okresie z 1,2 bln USD do 3,5 bln USD, czyli o $191 \%$.

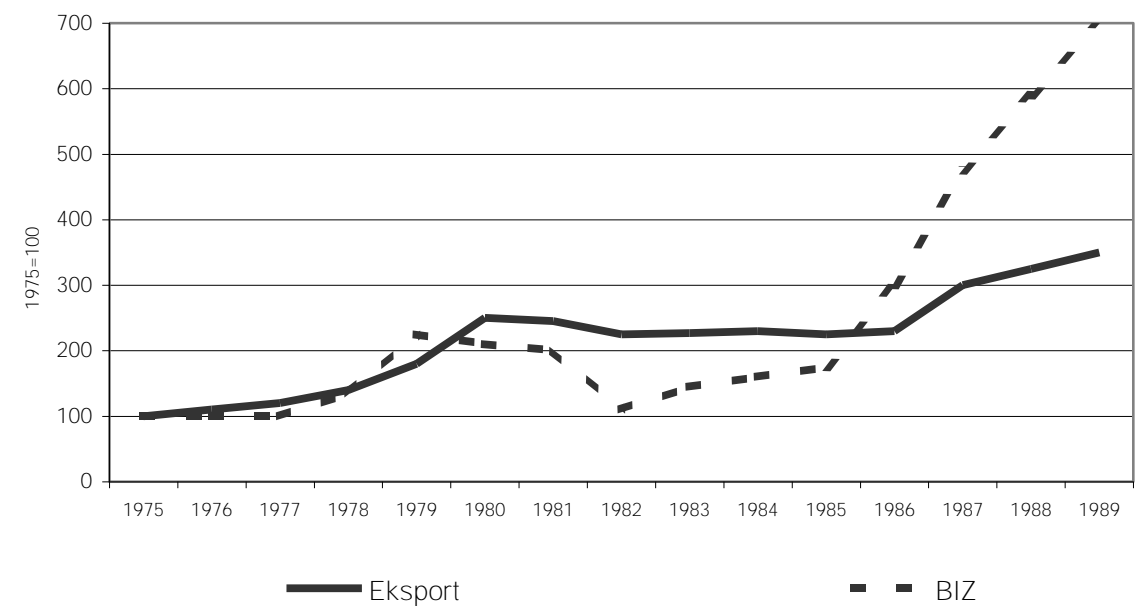

Ryc. 5. Dynamika eksportu i bezpośrednich inwestycji zagranicznych w latach 1975-1989

Źródło: World Investment Report, 1991

Biorąc pod uwagę wartość obrotów pochodzących z filii zagranicznych największą korporacją międzynarodową jest General Electric z USA, a następnie EXXON Mobil Corp. (USA), Royal Dutch / Shell Group (Niderlandy / Wielka Brytania), General Motors (USA) oraz Ford Motor Co. (USA). W pierwszej dziesiątce jest 5 korporacji ze Stanów Zjednoczonych (tab. 2). Świadczy to o wyraźnej dominacji tego kraju w światowej gospodarce przełomu XX i XXI wieku.

Analizując strukturę 100 największych korporacji wg rodzaju prowadzonej przez nie działalności wyraźnie widać dominację $4 \mathrm{z}$ tych działalności (produkcja elektroniki, wyrobów chemicznych i farmaceutycznych, środków transportu oraz wyrobów petrochemicznych). Udział tych firm w latach 90. był w zasadzie niezmienny i oscylował w grani- 
cach 58-61\% korporacji. Są to z jednej strony firmy technologiczne, a z drugiej reprezentujące tradycyjne działy przemysłu, np. produkcję samochodów czy paliw. Warto zwrócić uwagę na malejącą rolę działalności schyłkowych, takich jak przemysł metalowy, maszynowy czy budownictwo. O ile w 1990 roku było 13 takich korporacji, to po 9 latach jedynie 4. Świadczy to jednoznacznie o większej ekspansywności działalności związanych z nowymi technologiami czy z szeroko rozumianym sektorem usług (w tym mediów i telekomunikacji). Na znaczeniu zyskują także korporacje o zdywersyfikowanej produkcji, którym łatwiej sprostać konkurencji na wymagającym rynku globalnym (tab. 3).

Tabela. 2. Największe korporacje międzynarodowe w 1999 roku wg wielkości obrotów pochodzących z filii

\begin{tabular}{|c|l|l|l|r|r|}
\hline \multirow{2}{*}{ Lp. } & \multicolumn{2}{|c|}{ Korporacja } & \multicolumn{2}{|c|}{ Kraj } & \multicolumn{2}{c|}{ Rodzaj działalności } & \multicolumn{2}{c|}{$\begin{array}{c}\text { Obroty } \\
\text { (mld USD) }\end{array}$} \\
\cline { 5 - 7 } & & & & filii & lączne \\
\hline 1. & General Electric & USA & elektronika & 141,1 & 405,2 \\
\hline 2. & Exxon Mobil Corp. & USA & petrochemia & 99,4 & 144,5 \\
\hline 3. & Royal Dutch / Shell Group & $\begin{array}{l}\text { Niderlandy / } \\
\text { Wielka Brytania }\end{array}$ & petrochemia & 68,7 & 113,9 \\
\hline 4. & General Motors & USA & produkcja samochodów & 68,5 & 274,7 \\
\hline 5. & Ford Motor Co. & USA & produkcja samochodów & - & 273,4 \\
\hline 6. & Toyota Motor Corp. & Japonia & produkcja samochodów & 56,3 & 154,9 \\
\hline 7. & Daimler Chrysler AG & Niemcy & produkcja samochodów & 55,7 & 175,9 \\
\hline 8. & Total Fina SA & Francja & petrochemia & - & 77,6 \\
\hline 9. & IBM & USA & $\begin{array}{l}\text { elektronika / kompute- } \\
\text { ry }\end{array}$ & 44,7 & 87,5 \\
\hline 10. & BP & Wielka Brytania & petrochemia & 39,3 & 52,6 \\
\hline
\end{tabular}

Źródło: World Investment Report, 2001

Tabela. 3. 100 największych korporacji transnarodowych wg rodzaju działalności w latach $90 . \mathrm{XX}$ wieku

\begin{tabular}{|c|l|c|c|c|}
\hline Lp. & \multicolumn{1}{|c|}{ Rodzaj działalności } & 1990 & 1996 & 1999 \\
\hline 1. & Przemysł elektroniczny & 14 & 17 & 18 \\
\hline 2. & Przemysł chemiczny i farmaceutyczny & 18 & 16 & 16 \\
\hline 3. & Przemysł środków transportu & 13 & 14 & 14 \\
\hline 4. & Przemysł petrochemiczny & 13 & 14 & 12 \\
\hline 5. & Przemysł spożywczy. Produkcja napojów & 9 & 12 & 8 \\
\hline 6. & Telekomunikacja & 2 & 5 & 3 \\
\hline 7. & Handel & 7 & 4 & 7 \\
\hline 8. & Przemysł maszynowy & 3 & 2 & 1 \\
\hline 9. & Przemysł metalowy & 6 & 3 & 1 \\
\hline 10. & Budownictwo & 4 & 3 & 2 \\
\hline 11. & Media & 2 & 2 & 4 \\
\hline 12. & Produkcja zdywersyfikowana & 2 & 4 & 7 \\
\hline 13. & Inne & 7 & 4 & 7 \\
\hline
\end{tabular}

Źródło: World Investment Report, 1998; World Investment Report, 2001

Struktura geograficzna firm macierzystych oparta na wartości TNI (Transnationality Index powstał jako średnia arytmetyczna $\mathrm{z}$ sumy udziałów filii $\mathrm{w}$ łącznych obrotach, 
sprzedaży i zatrudnieniu) wskazuje na wyraźną dominację korporacji, których siedziby zlokalizowane są w krajach o relatywnie małych rynkach wewnętrznych, natomiast posiadających duże zasoby kapitału inwestycyjnego. Często dla utrzymania tendencji wzrostowych firmy takie są niejako zmuszone do inwestowania za granicami, gdyż chłonność rynku krajowego na produkty tych korporacji jest już optymalna. Należy podkreślić, iż korporacje o najwyższej wartości TNI kreują nowe miejsca pracy, co jest istotne dla państw odbiorców inwestycji. Firmy te reprezentują zarówno tradycyjne działy, np. produkcję żywności czy budownictwo, jak i nowoczesne, np. elektronikę, media czy farmację. Spośród 10 korporacji

o najwyżej wartości TNI aż 4 reprezentują Szwajcarię, 2 Kanadę, a pozostałe Szwecję,

Niderlandy i Wielką Brytanię (tab. 4).

Tabela 4. Największe korporacje międzynarodowe wg wielkości TNI w 1999 roku

\begin{tabular}{|c|c|c|c|c|c|c|c|c|c|c|}
\hline \multirow[t]{2}{*}{ Lp. } & \multirow[t]{2}{*}{ Korporacja } & \multirow[t]{2}{*}{ Kraj } & \multirow{2}{*}{$\begin{array}{c}\text { Rodzaj } \\
\text { działalności }\end{array}$} & \multicolumn{2}{|c|}{$\begin{array}{c}\text { Obroty } \\
\text { (mld USD) }\end{array}$} & \multicolumn{2}{|c|}{$\begin{array}{c}\text { Sprzedaż } \\
\text { (mld USD) }\end{array}$} & \multicolumn{2}{|c|}{$\begin{array}{l}\text { Zatrudnienie } \\
\text { (osoby) }\end{array}$} & \multirow{2}{*}{$\begin{array}{l}\text { TNI } \\
(\%)\end{array}$} \\
\hline & & & & filie & ogółem & filie & ogółem & filie & ogółem & \\
\hline 1. & $\begin{array}{l}\text { Thomson } \\
\text { Corp. }\end{array}$ & Kanada & media & 13,6 & 13,8 & 5,5 & 5,8 & 37000 & 40000 & 95,4 \\
\hline 2. & Nestle SA & Szwajcaria & $\begin{array}{l}\text { produkcja } \\
\text { żywności }\end{array}$ & 33,1 & 36,8 & 45,9 & 46,7 & 224554 & 230929 & 96,2 \\
\hline 3. & $\mathrm{ABB}$ & Szwajcaria & $\begin{array}{l}\text { urządzenia } \\
\text { elektryczne / } \\
\text { elektronika }\end{array}$ & 27,0 & 30,6 & 23,8 & 24,4 & 155427 & 161430 & 94,1 \\
\hline 4. & Electrolux $\mathrm{AB}$ & Szwecja & \begin{tabular}{|l|} 
urządzenia \\
elektryczne / \\
elektronika
\end{tabular} & 9,1 & 9,8 & 13,9 & 14,5 & 84035 & 92916 & 93,2 \\
\hline 5. & Holcim & Szwajcaria & budownictwo & 12,5 & 13,6 & 7,3 & 8,1 & 36719 & 39327 & 91,8 \\
\hline 6. & Roche Group & Szwajcaria & $\begin{array}{l}\text { produkcja } \\
\text { leków / } \\
\text { chemia }\end{array}$ & 24,5 & 27,1 & 18,1 & 18,4 & 57970 & 67695 & 91,5 \\
\hline 7. & \begin{tabular}{|l} 
British \\
American \\
Tabacoo Plc \\
\end{tabular} & $\begin{array}{l}\text { Wielka } \\
\text { Brytania }\end{array}$ & $\begin{array}{l}\text { produkcja } \\
\text { żywności }\end{array}$ & 22,0 & 26,2 & 16,5 & 18,1 & 104223 & 107620 & 90,7 \\
\hline 8. & Unilever & \begin{tabular}{|l} 
Wielka \\
Brytania / \\
Niderlandy
\end{tabular} & $\begin{array}{l}\text { produkcja } \\
\text { żywności }\end{array}$ & 25,3 & 28,0 & 38,4 & 44,0 & 222614 & 246039 & 89,3 \\
\hline 9. & $\begin{array}{l}\text { Seagram } \\
\text { Company }\end{array}$ & Kanada & $\begin{array}{l}\text { produkcja } \\
\text { żywności }\end{array}$ & 25,6 & 35,0 & 12,3 & 11,8 & - & - & 88,6 \\
\hline 10. & $\begin{array}{l}\text { Akzo } \\
\text { Nobel NV }\end{array}$ & $\begin{array}{l}\text { Niderlan- } \\
\text { dy }\end{array}$ & $\begin{array}{l}\text { przemysł } \\
\text { chemiczny }\end{array}$ & 10,2 & 12,0 & 12,6 & 15,4 & 55100 & 68000 & 82,6 \\
\hline
\end{tabular}

Źródło: World Investment Report, 2001

Wzrost międzynarodowych operacji przedsiębiorstw, przyspieszony rozwój technologiczny i zwiększona presja konkurencyjności u progu XXI wieku to czynniki, które wzmagają zainteresowanie przedsiębiorstw strategią wzrostu zewnętrznego. Prowadzona w ostat-nich latach przez czołowe korporacje walka konkurencyjna w skali globalnej spowodowała, że zachodziły procesy koncentracji zasobów międzynarodowych koncernów. 
Obserwuje

się konsolidację firm tej samej branży lub branż pokrewnych (np. w przemyśle farmaceutycznym Ciba-Geigy i Sandoz, GlaxoWellcome i SmithKline Beecham, spożywczym -

Bestfoods i Unilever, telekomunikacji - Ameritech i SBC), ale coraz częstsze są również połączenia międzysektorowe mające na celu utworzenie globalnych firm multimedialnych (połączenie "klasycznych" mediów i Internetu, np. America OnLine i Time Warner czy Vodafone Air Touch i Mannesman). O sukcesie połączonych przedsiębiorstw decyduja przede wszystkim kompetencje technologiczne, poziom innowacyjności oraz zarządzanie. Można więc pokusić się o stwierdzenie, że współczesnym procesom internacjonalizacji i globalizacji gospodarki nadają kierunek największe korporacje.

$\mathrm{Z}$ badań przeprowadzonych na podstawie World Investment Report wynika, że korporacje międzynarodowe wykazują silną koncentrację geograficzną. Spośród 100 największych KTN w 1999 roku 91 związanych było z Triadą gospodarczą (USA, Japonia, UE). W latach 1985-1999 strumień inwestycji między tymi obszarami gospodarczymi powiększył się, z wyraźnym ożywieniem kontaktów między USA i UE oraz Japonią i UE. O ile w latach 80. źródłem kapitału inwestycyjnego była Unia Europejska, to na przełomie lat 80. i 90. inicjatywę przejęły pozostałe dwa bieguny wzrostu gospodarczego (ryc. 6).
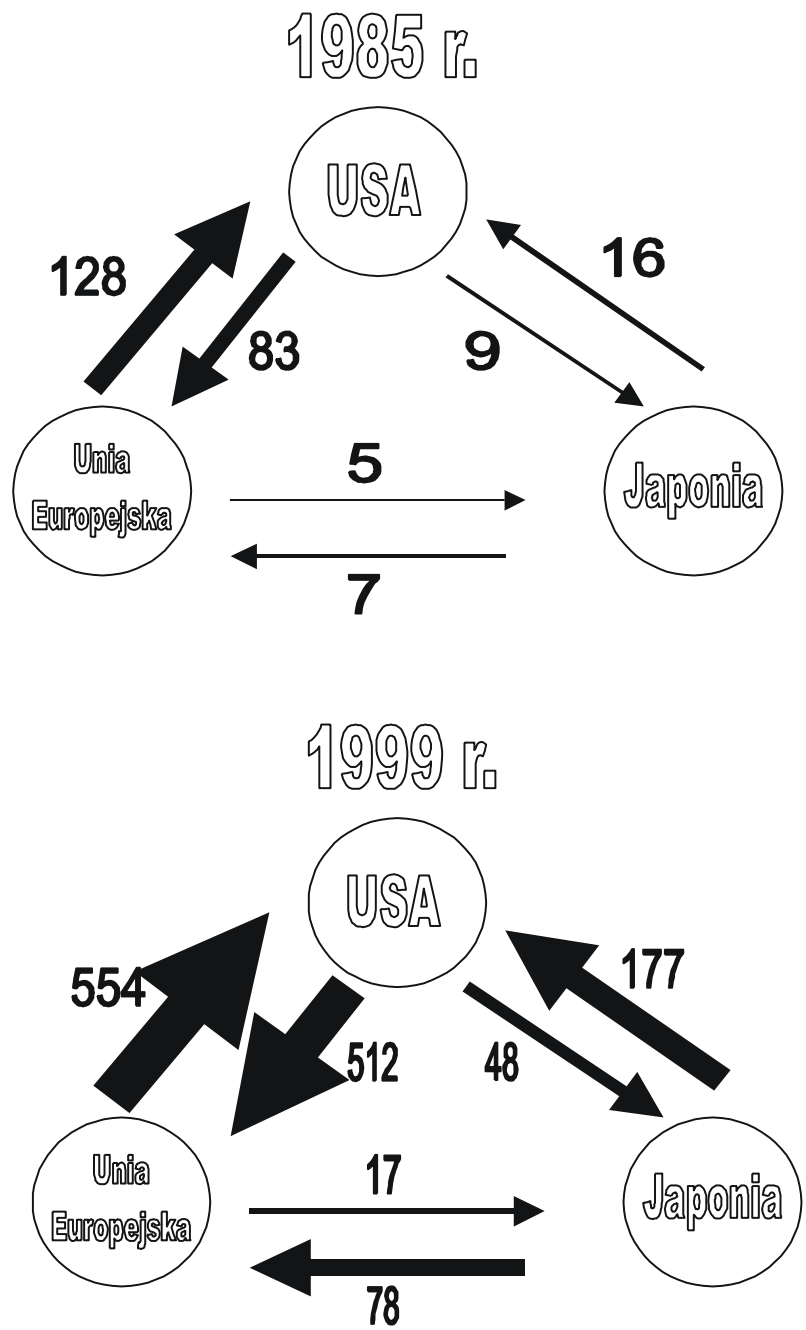
Ryc. 6. Skumulowane wartości napływu inwestycji zagranicznych w obrębie Triady w mld USD

Źródło: World Investment Report, 2001

Przeprowadzone rozważania wskazują, że tworzenie się coraz większych korporacji jest wynikiem dynamicznego wzrostu gospodarczego w skali światowej, presji na rynku krajowym i międzynarodowym, przyspieszonego rozwoju technologicznego i wzrostu międzynarodowych operacji przedsiębiorstw. Wydaje się, że w pewnych aspektach tak masowe działania wymykają się racjonalnej ocenie, dlatego coraz częściej dominująca pozycja wielkich przedsiębiorstw na rynku jest ograniczana (z różnym skutkiem) przez urzędy antymonopolowe. Jednakże ogromny potencjał ekonomiczny tego typu korporacji rodzi obawy, że ich zachowania mogą zaszkodzić rozwojowi gospodarki państw oraz ich stabilności. Już teraz na 100 największych potęg gospodarczych świata (krajów i firm) jedynie 49 to państwa. Łączna wartość sprzedaży 200 największych korporacji międzynarodowych (27,5\% światowego PKB) jest większa niż suma PKB wszystkich krajów, pomijając 10 największych. Przy ogólnej tendencji do liberalizmu w gospodarce pojawiają się postulaty reregulacji, czyli objęcia kontrolą poczynań wielkich korporacji.

\section{Literatura}

Czupiał J., 1997, Organizacja przedsiębiorstw wielonarodowych, [w:] Struktury przemysłowe w gospodarce. Aspekty ekonomiczne, społeczno-kulturowe i polityczne, red. L. Olszewski, J. Mozrzymas, Wrocław

Gospodarka Polski wobec globalnych wyzwań rozwoju, 2000, pod red. W. Kowalczewskiego, Warszawa

Lewandowski M., 2001, Fuzje i przejęcia w Polsce na tle tendencji światowych, Warszawa

Pierścionek Z., 1997, Strategie rozwoju firmy, Warszawa

Wieloński A., 1996, Rola korporacji transnarodowych w restrukturyzacji przemysłu Polski, "Geografia w Szkole" nr 3, s. 136-138

Wieloński A., 2000, Geografia przemystu, Warszawa

World Investment Report, 1991, UNCTAD, United Nations, New York and Geneva

World Investment Report, 2001, UNCTAD, United Nations, New York and Geneva

Zioło Z., 2001, Struktura branżowa i koncentracja przestrzenna wiodacych światowych firm przemystowych, [w:] Problemy przemian struktur przemystowych $w$ procesie wdrażania regut gospodarki rynkowej, pod red. Z. Zioło, Prace Komisji Geografii Przemysłu nr 1, Warszawa-Kraków

Zorska A., 1998, Ku globalizacji? Przemiany $w$ korporacjach transnarodowych $i w$ gospodarce światowej, Warszawa 